\title{
Strengthening Halal Industry in Increasing Competitiveness and Economic Opportunities in Industrial Revolution Era 4.0
}

\author{
Eko Siswoyo ${ }^{1^{*}}$ \\ ${ }^{1}$ Sharia Economics Department, Postgraduate Faculty, State Institute Islamic Studies (IAIN) Kudus
}

\begin{abstract}
The development of the halal industry has the potential and continues to experience growth and the opportunity to become a country with the largest productive status in the world. However, the development of the halal industry still requires strengthening policies and regulations in optimizing the existing potential and challenges. This study aims to provide an overview of Indonesia's position and the competitiveness of the halal industry in the era of the industrial revolution 4.0. The method used is descriptive qualitative with an exploratory approach and the research data is processed using qualitative analysis. The results of the study show that the halal industry ecosystem with halal certification and brand image is an important indicator in strengthening competitiveness. Meanwhile, opportunities from the Islamic finance sector, halal tourism, Muslim tourists and market share have great potential in increasing economic growth. On the other hand, Indonesia must overcome challenges related to the low awareness of halal products from the industrial sector and the imbalance in the distribution of halal product supply chain.
\end{abstract}

Keywords: Halal Industry, Market Opportunities and Economic Growth

\section{Introduction}

The development of halal industry has become a trend in planning development strategies in Indonesia. This is in line with the prospect of the halal industry which continues to grow every year. According to a report from the State of Global Islamic Report (2020) there are around 1.95 billion Muslim residents worldwide who are consumers of the halal industry. This potential increases by $5.2 \%$ every year with total consumer spending reaching USD 2.2 billion. The halal industry is projected to continue to increase to reach $6.2 \%$ in the span of 2018 to 2024. Indonesia is categorized in the top 10 largest consumer countries in each industrial sub-sector. Ranked first in the top Muslim food expenditure, seeing this certainly makes Indonesia have greater potential in developing economy for continue to grow compared each other countries through strengthening the halal industry sector and the halal product supply chain ecosystem. Data compiled from Compound Annual Growth Rate (CAGR) estimates that total funds spent by consumers of the halal industry will reach USD 3.2 billion in 2024. Thus, the potential for the development of the halal industry in Indonesia is very large and has bright prospects in the next few decades. According to the Ministry of

* Corresponding author: ekosiswoyo37@gmail.com 


\section{$A I \bar{C} \quad$ Annual International Conference \\ on Islamic Economics and Business, 2021}

Industry Indonesia (2020) the halal industry has begun to develop rapidly in Indonesia, especially the MSME sector, followed by market potential and demand for halal products by consumers. In addition, the opportunity to develop a halal industrial zone is very large. This is due to the increasing demand for halal products such as food, beverage sector and cosmetics sector.

The era of industrial revolution 4.0 caused market competition to become very tight in all industrial sectors. With the start of industry 4.0, every company competes with each other to obtain information in taking appropriate and fast action as the best strategy. On the other hand, entrepreneurs are starting to think about creating a competitive advantage through the use of digital-based technology. It is feared that this situation will damage the order of the business model that takes place in each business unit on a varying scale. One of the impacts that will occur is to advance the company's performance, especially in marketing a halal product. Thus, the economic sector will experience significant growth both on a macro and micro scale. Company performance is a picture of the industry as a whole in a certain period which is the result that has been achieved through the strategies and policies that have been implemented. The halal industry has a strategic role in improving the economy in Indonesia.

Despite the enormous potential, opportunities in the economic field at both national and global levels according to data from the State of The Global Islamic Economy in 2020, placing Indonesia in fourth and experiencing an increase compared to 2019 in fifth place and 2018 in tenth place. Indonesia should be a country with great potential in the halal industry, because the Muslim population with the largest number in the world reaches 209.1 million people or $87.2 \%$ of the total population of Indonesia (Mubarok \& Imam, 2020). This percentage figure already represents $13.1 \%$ of the total population of Muslims scattered throughout the world. According to data from the Ministry of Finance (2020), the contribution of the halal industry in the national economy to GDP increased to $24.86 \%$ in 2020. This is in line with the increasing market share of the halal product sector in the global market. Therefore, the halal industry has had an impact on the Indonesian economy by donating USD 1 billion in investment from foreign investors and providing employment opportunities for around 127 thousand new jobs every year. Opportunities for the business model economy in the Industrial Era 4.0. First, as a solution to the problems that exist in society. Second, in this era, you will never be satisfied with the results achieved so that you will continue to encourage innovation from the industry. Third, the new monopolistic model of capitalism by embracing the economic notion of sharing countries so that it will be a solution to economic inequality. Fourth, the industrial era 4.0 marketing model utilizes information technology and internet-based application systems that will provide major changes to the economy. On the other hand, the rapid development of information technology will automatically spread to all fields, new technologies and approaches that will combine real, digital and fundamental (Tjandrawinata, 2016). The government's efforts to strengthen the halal industry sector have been carried out with regulations issued through Law No. 33 of 2014 concerning Halal Product Assurance (JPH) and the establishment of the Halal Product Guarantee Agency (BPJPH). This condition is a step taken by the government with the right regulations in optimizing the opportunities for the halal industry in the era of the industrial revolution 4.0 in Indonesia.

Based on the above background, researchers are interested in conducting research related to strengthening the halal industry sector and opportunities for the Indonesian economy. Given the huge potential that the market has in Indonesia, an acceleration strategy in the development of the halal industry is needed, one of which is increased competitiveness and appropriate regulatory regulations from the government. This is an opportunity for Indonesia as a country with a high labor force and unemployment rate to be able to respond to these changes appropriately through the preparation of strategies that are expected to increase the 


\section{$A I C \overline{I E B} \quad$ Annual International Conference \\ on Islamic Economics and Business, 2021}

competitiveness of the halal industry and in the era of the industrial revolution 4.0 which is currently increasingly encouraging economic growth in Indonesia.

\section{Method}

This research is a qualitative descriptive study with an exploratory approach. With data obtained from various literatures that discuss the strengthening of the halal industry and opportunities in the era of the industrial revolution 4.0 to the economy in Indonesia. Kotler $\&$ Keller (2006) state that the exploratory approach is a research method that aims to collect initial information that will assist the author in establishing problems and formulating hypotheses. The definition of a descriptive approach is a research method that aims to describe or explain something that will be explained in the discussion. Sources of data in this study using primary and secondary sources in the form of books and journals. The data collection technique is carried out by literature study. Analysis of the data needed in the literature study is obtained from a number of references that are considered to have an attachment to the problem to be studied and can support problem solving that occurs. The data obtained were analyzed using qualitative data analysis techniques.

\section{Result and Discussion}

\subsection{Halal Industry Strengthening Ecosystem in Indonesia}

The halal industry ecosystem can be interpreted as a condition where the environment influences dynamics of the development and growth rate of halal industry which includes control guidelines, regulations, governance procedures, character of stakeholders and regulations (Annisa, 2019). The ability of logistics distribution is one of the determinants of the success of the halal industry in increasing competitiveness in the global market. In strengthening the halal industry, the halal industry must be able to change its comparative advantage to a competitive advantage where the ability of the industry is based on ownership of resources such as demographic bonuses and resource wealth. With the management and utilization of resource ownership, it is expected to be able to increase added value based on innovation and technology, as well as the superiority of human resources (Nasution, 2020). Several strategies can be implemented to strengthen the halal industry in market competition.

First, halal competency certification, which is one of the solutions for efforts to create and prepare products that can compete in the global market. With the existence of halal certification, of course, the industrial sector must adjust to the procedures in the production process in accordance with a series of halal products including the provision of materials, processing, storage, packaging, distribution, sales and product presentation. So that the halal status of a product can be known with certainty and the interests of consumers for halal products according to Islamic law will be guaranteed. Second, the brand image that characterizes the brand of an item. Brand image is the way people know and perceive the brand in actual. In order for the brand image to be embedded in the minds of consumers, it is necessary to pay attention to brand identity through available communication and brand contacts (Kotler \& Keller, 2016). Thus, the existence of halal assurance through halal certification and brand image of halal products will change consumer perceptions about halal products and consumer confidence in these two things will continue to be embedded in the memory and summarized in the memory of consumers. 


\section{$A \mathrm{IC} \quad$ Annual International Conference \\ on Islamic Economics and Business, 2021}

\subsection{Role of Halal Industry on Economic Growth}

Economic growth is a parameter in encouraging the success of a country's development. Gross Domestic Product (GDP) is one of the assessments of economic growth. According to Central Statistics Data (BPS), Indonesia's economy in 2020 as measured by gross domestic product at current prices reached IDR $15.434,2$ billion and GDP per capita of IDR 56.9 million USD 3.911,7. GDP is the amount of added value obtained from all business units in a country in a certain period. Economic growth is considered important because of the relationship with the welfare of the community so that the economy must continue to be stable and increase, as a result the national human development index will also increase (Krisna \& I Ketut, 2014). Entering the era of industrial revolution 4.0, as a country with the largest Muslim population in the world, Indonesia has the advantage in developing industry and increasing export activities in the market sector of halal products. This condition will be directly proportional to increase in the number of Muslims and of course the demand for consumption of halal products. The halal product market is a promising sector because of the need for Muslims for goods and services. In meeting the demands of Islamic law, it is necessary to have a supply chain and demand that will increase the diversity of halal products circulating in the market to meet consumer needs.

Export sector is also the main focus that has an impact on economic growth. Exports are superior and driven by the presence of competitive advantages as an important factor that will become a major player in increasing export volume. Based on OIC Economic Outlook 2020, among OIC member countries, Indonesia is the fifth largest exporter with a proportion of $9.3 \%$. Competitive advantage is the ability of an industry's competitiveness and has an important role in the global market. This competitiveness will help the industry in facing its competitors in the industrial sector. In order for an industry to achieve a national competitive advantage, export activities in their execution need attention to the skills and resources they have in order to support these activities. In the global market competition, the suitability of resources and skills used needs to remain a concern in order to obtain a competitive advantage that will later support the success and improvement of the export sector. Export success is also not only determined by economic factors such as costs or prices, but is more determined by the products and services that can be provided as a form of high performance that will give birth to a competitive advantage in an industrial sector (Piercy et al., 1998).

Table 1. Economic Growth compared to Foreign Exchange Reserves and Export Value

\begin{tabular}{|c|c|c|c|}
\hline Year & $\begin{array}{c}\text { Foreign Exchange Reserves } \\
\text { (Million USD) }\end{array}$ & $\begin{array}{c}\text { Export Value } \\
\text { (Million USD) }\end{array}$ & $\begin{array}{c}\text { Growth } \\
\text { Economy (\%) }\end{array}$ \\
\hline 2015 & 105.031 & 150.366 & 4,79 \\
\hline 2016 & 116.362 & 145.186 & 5,02 \\
\hline 2017 & 130.196 & 168.828 & 5,07 \\
\hline 2018 & 120.654 & 180.012 & 5,17 \\
\hline 2019 & 123.800 & 167.497 & 5,02 \\
\hline 2020 & 135.900 & 163.191 & $-2,07$ \\
\hline
\end{tabular}

Source: Central Bureau of Statistics (BPS) (Processed data, 2021)

In international trade competition, export activities need financing from the country's foreign exchange reserves. In general, the country's foreign exchange reserves are a very important monetary indicator as a strong indication of whether or not a country's economic fundamentals are strong. In addition, a sufficient amount of foreign exchange reserves is one of the guarantees for achieving monetary and macro economic stability of a country (Tambunan, 2001). The position of foreign exchange reserves, whether large or small, depends on various factors that affect each element in Indonesia's balance of payments. While 


\section{$A I \overline{C E B}$ Annual International Conference \\ on Islamic Economics and Business, 2021}

the outcome target of competitiveness is inclusive and sustainable economic growth, which can ensure equitable distribution of welfare through employment and poverty alleviation in the community. The following is Central Bureau of Statistics (BPS) data related to economic growth and compared to foreign exchange reserves and export values from 2015 to 2020.

Based on table 1 above, it shows that with the highest export value in 2018 with economic growth at $5.17 \%$. This indicates the importance of the export sector in an industry, that the greater the industry's ability to maximize export potential will certainly have an impact on increasing the percentage of economic growth in Indonesia. The large market potential of the halal industry in Indonesia can add value to foreign exchange reserves. There are 3 things that need to be done by business actors and the Indonesian halal industry in increasing competitiveness. First, Improving the quality of the products produced to comply with the standards in the international market. The pattern of consumers who buy products from the halal industry is not only based on the halal label, but also the quality of the product in creating a new lifestyle where products that have good quality will be highly ogled and become a consideration for consumers to buy these products. The definition of product quality is any action or activity that one party can offer to another, which is essentially intangible and does not result in any ownership (Nalendra et al., 2019). While the purchase decision is a decision based on the actions and thoughts of consumers in deciding to purchase by making considerations including, fulfilling needs, understanding needs, the process of looking for goods, the process of evaluation and decision making (Buyung et al., 2016). Second, fulfill production capacity, so that skills in production must be adequate.

The greater the market potential, the greater the impact on the halal product producer sector. According to Handoko (2001) production capacity is a level of output, a quantity of output in a certain period and is the highest output during a certain period. The relationship of product capacity is certainly influenced by product demand, where the total population of Indonesia is estimated at 273 million people or $87.2 \%$ of the total population in Indonesia (World Population Review, 2020). With the large population level, the demand for halal products will be even greater. The large capacity and high demand for products make Indonesia the embodiment of the center of the world halal industry market. Of course in the future it will have an impact with greater economic growth in Indonesia. Third, there is continuity, namely products from the halal industry are always produced, so that they are always ready stock on an ongoing basis. Product availability is part of a manufacturer's collection of merchandise that includes product categories and variations in each category (Evans \& Berman., 2001). The company uses distribution channels as an effort to distribute products to consumers with the best service with the aim of getting satisfaction from consumers. Distribution strategy and product availability become one of the important factors in getting the influence of buying interest and consumer satisfaction (Kotler \& Keller, 2016). The availability of products certainly makes it easier for consumers to choose and obtain the expected products. Consumers will feel satisfied if the product is readily available and easy to obtain. Therefore, the product must be distributed by the company properly so that it is easily accessible to consumers. Thus, the availability of the product is an effective way that is fast and appropriate to fulfill what the wants and expectations of consumers are in a way that is easily accepted.

\subsection{Potential and Challenges of Halal Industry in Indonesia}

Indonesia already has a relatively increasing halal industry ecosystem. The projection of the halal industry which continues to increase by $5.2 \%$ every year with consumer spending reaching USD 2.2 billion and is predicted to reach $6.2 \%$ in 2024 will be a great potential for the existence of the halal industry in Indonesia. However, the development of the halal industry is still faced with many challenges. This is in line with the many cases in various 


\section{$A I \overline{C E B}$ Annual International Conference \\ on Islamic Economics and Business, 2021}

countries in responding to and facing challenges in the development of a diverse halal industry (Rahmayati, 2020). In terms of potential, Indonesia in maximizing the existence of the halal industry is supported by abundant natural resources. With the wealth of natural products, Indonesia has great potential to continue to innovate in developing halal products. The number of Indonesian Muslim population is very large compared to other Muslim countries which is also a potential market for the halal industry. In addition, there are several sectors that become opportunities in the future, namely the halal food sector, the Islamic finance sector, the halal tourism sector and the textile sector. According to data obtained from the Islamic Finance Country Index (IIFCI) score in 2021, Indonesia ranks first with an index score of 83.35 followed by Saudi Arabia with an index score of 80.67 in second place and completing the top 3 is Malaysia with an index score of 80.01 . From the sector of potential for halal tourism, Indonesia has received great attention from the world. Indonesia ranks as the top country in the Top 10 OIC destination category, with an index score of 78 . The score is the same as that obtained by Malaysia and in third place is Turkey with an index score of 75. Based on data from according to the Global Muslim Travel Index, the number of Muslim tourists Globally in 2020 it will reach 160 million people and it is estimated that by 2026 it will increase to 230 million people. Of course, Indonesia has a great opportunity to become a country with the largest Muslim tourist visits through the development of a tourism destination sector that attracts foreign tourists. From the halal food sector in 2020, Indonesia has a national market share to the global, showing that Indonesia has great potential, reaching $13 \%$ of the world's total consumption of halal food. However, Indonesia is the largest food importing country in the world, reaching USD 14.29 billion. The existence of government support for the halal industry through the ratification of law no. 33 of 2014 concerning halal product guarantees will make the market potential to continue to grow even greater. The existence of a halal product guarantee regulation for a product has an impact on the ability of competitiveness in the face of global competition. On the other hand, it is necessary for development in many sectors that are in their infancy with high quality and competitiveness.

The development of the halal industrial sector in Indonesia is certainly not easy and there are challenges that are inhibiting factors for economic growth. According to Fauzi et al., (2017) there are at least 2 main aspects, namely aspects of upstream to downstream production and regulatory aspects. In terms of upstream production, there are still many producers who do not have a good understanding of information related to halal products including aspects of financing, raw materials, production, marketing and supply chain control. Thus, the production process is only limited to understanding the product processing and is not comprehensive and will have an impact on downstream production such as the distribution process of halal products. This situation will certainly affect the inhibition of the creation of renewable innovations in accelerating the growth of the halal industry Nasution, (2020). The hope is that with the innovations that are raised, they will become a competitive advantage in market competition. Meanwhile, from the regulatory aspect, the lack of commitment from industry players in creating supply chain integrity is one of the causes of the inhibition of the growth of the halal industry. This can be reflected in the low investment in specific assets that can serve the needs of fulfilling halal products, especially those that have the potential for export share (Mohamad \& Backhouse, 2014). The challenges in making a halal standard supply chain and logistics management that apply in maintaining the integrity of halal products need to be improved in the hope of improving the distribution process. With low awareness and supply chain imbalances, it must be a common concern so that the development of the halal industry continues to grow and in the future it can become a country with the largest productive status in the halal industry. 


\section{$A I C \bar{C} \quad$ Annual International Conference \\ on Islamic Economics and Business, 2021}

\section{Conclusion}

In the development of halal industry, Indonesia has enormous potential to become the country with the largest productive status in the world. Economic growth as a result of the growing development of various sectors of the halal industry in Indonesia further strengthens competitiveness. The use of digital-based technology and appropriate regulatory regulations from the government will clarify Indonesia's position in the halal industry sector with a competitive advantage. Overall, the success of the halal industry sector requires the support of all relevant parties. In addition, ownership of resources such as demographic bonuses and abundant natural resource wealth will increase the added value of halal products based on innovation and technology, as well as the superiority of human resources Indonesia in the future.

\section{References}

Annisa, A. A. (2019). Kopontren dan Ekosistem Halal Value Chain. Jurnal Ilmiah Ekonomi Islam, 5(01), 1. https://doi.org/10.29040/jiei.v5i01.398

Buyung, S., Mandey, S. L., \& Sumarauw, J. S. . (2016). Pengaruh Citra Merek,Kualitas Produk Dan Harga Terhadap Keputusan Pembelian Produk Semen Tiga Roda Di Toko Lico. Jurnal Berkala Ilmiah Efisiensi, 16(4), 376-386.

Evans, J. R., \& Berman., B. (2001). Retail Management (8th ed.). Prentice Hall.

Fauzi, F. A., Karia, N., \& Mokhtar, M. A. M. (2017). The antecedents of Halal competency model: Towards improvement of Halal certification for SMFEs' products. International Journal of Business, Economics and Law, 14(5), 18-28.

Handoko, T. H. (2001). Manajemen Personalia Dan Sumber Daya Manusia. BPFE.

Kementrian Keuangan Reublik Indonesia. (2020). Media Keuangan.

Kementrian Perdagangan Republik Indonesia. (2020). Indonesia Digadang Jadi Pusat Produksi Halal Dunia.

Kotler, P., \& Keller, K. L. (2006). Metodologi Penelitian: Aplikasi Dalam Pemasaran. Indeks.

Kotler, P., \& Keller, K. L. (2016). Marketing Management. Pearson Education.

Krisna, D. P. A., \& I Ketut, S. (2014). Pengaruh Kemandirian Keuangan daerah Dan Pertumbuhan ekonomi Terhadap indeks Pembangunan manusia Di Provinsi bali. EJurnal Ekonomi Pembangunan Universitas Udayana, 4(1), 32-40. https://ojs.unud.ac.id/index.php/eep/article/download/10591/8167

Mohamad, N., \& Backhouse, C. (2014). A Framework for the Development of Halal Food Products in. International Conference on Industrial Engineering and Operations Management, 7(9), 693-702.

Mubarok, F. K., \& Imam, M. K. (2020). Halal Industry in Indonesia; Challenges and Opportunities. Journal of Digital Marketing and Halal Industry, 2(1), 55. https://doi.org/10.21580/jdmhi.2020.2.1.5856

Nalendra, A. R. A., Winarno, S. H., Susanti, I. D., \& Latumahina, J. (2019). Pengaruh Kualitas Produk, Harga Dan Citra Merek Produksi Tiongkok Terhadap Keputusan Pembelian (Studi Kasus Hp Android Xiaomi). Jurnal Mitra Manajemen, 3(12), 11711181. https://doi.org/10.52160/ejmm.v3i12.307

Nasution, L. Z. (2020). Penguatan Industri Halal bagi Daya Saing Wilayah : Tantangan dan Agenda Kebijakan. Journal of Regional Economics Indonesia, 1(2), 33-57.

Piercy, N. F., Kaleka, A., \& Katsikeas, C. S. (1998). Sources of competitive advantage in high performing exporting companies. In Journal of World Business (Vol. 33, Issue 4, pp. 378-393). https://doi.org/10.1016/S1090-9516(99)80081-9

Rahmayati, R. (2020). Islamic Banking Synergity As Halal Industry Development In 


\section{$A T C$ Annual International Conference \\ on Islamic Economics and Business, 2021}

Indonesia. Proceeding International Seminar of Islamic ..., 1(2015), 299-309.

State of Global Islamic Economy Report. (2020). State of Global Islamic Economy Report 2019/20. New York: Thomson Reuters.

Tambunan, T. (2001). Transformasi Ekonomi di Indonesia. Teori dan Penemuan Empiris. Salemba Empat.

Tjandrawinata, R. (2016). Industri 4.0: revolusi industri abad ini dan pengaruhnya pada bidang kesehatan dan bioteknologi. February. https://doi.org/10.5281/zenodo.49404

World Population Review. (2020). Word Population. http://worldpopulationreview.com/ 